\title{
Climatic Types, Their Distribution and Changes in Different Micro Meteorological Stations in Kathmandu Valley
}

\author{
Dambaru Ballab Kattel \\ Nepal Academy of Science and Technology, Khumaltar, Lalitpur \\ e-mail: katteldb@gmail.com
}

\begin{abstract}
The objective of this paper was to organize the information, classify and resolute the altered frequency of climatic types of different micrometeorological stations in Kathamndu valley (Kakani, Budhanilakantha, Godavari, Khumaltar, Airport, Panipokhari, Nagarkot, Khokana and Thankot). Analyzed data of the stations revealed the prevalence of " $\mathrm{C}$ " (humid mesothermal)as the major type of climate. But the "Cwa" and "Cwb" types of climate were not common for all stations of Kathmandu valley. In some stations the "Cfa "and "Cfb" types of climate were also found. The temperature of Kathmandu valley has been increasing as above the trend of global warming but not alarming result of temperature increment was noticed. During 1976 to 2006, the altered of climatic types were found only at Godavari, Khumaltar, Panipokhari and Thankot, but the altered frequency was less during the period of 30 years. The average temperature in winter $\left(11.55^{\circ} \mathrm{C}\right)$ and summer $\left(23.78^{\circ} \mathrm{C}\right)$ was found maximum at the Airport as compared to other stations. The thirty years total seasonal precipitation in summer was maximum at Kakani $(6890.12 \mathrm{~cm})$ and minimum at Khumaltar $(2715.58 \mathrm{~cm})$. However, the seasonal precipitation in winter was found maximum at Thankot $(205.58 \mathrm{~cm})$ and minimum at Khumaltar $(151.69 \mathrm{~cm})$.
\end{abstract}

Key words: Koppen's system, climatic types, temperature, precipitation, frequency analysis

\section{Introduction}

Climate is an important factor that not only helps in regeneration of plant life and growth of crops but also important to humankind. Human cannot tolerate too much cold or too much heat. Now the situation is different due to the multifarious activities of human the world's climate is warming. Global warming is the most urgent environmental problem the world is facing.

According to IPCC Report (2007) the global air temperature increasing trend is $0.6^{\circ} \mathrm{C}$ per decade and $0.06^{\circ} \mathrm{C}$ per year. However, the warming trend of Kathamndu valley is high as compare to global warming trend. The present increasing trend of temperature of Kathmandu valley is $0.8^{\circ} \mathrm{C}$ per decade and $0.08^{\circ} \mathrm{C}$ per year.(Wagle \& Kattel 2007)

The Kathmandu valley is situated at $1300 \mathrm{~m}$ above sea level with longitude and latitude $27^{0} 34^{\prime}-27^{\circ} 48^{\prime} \mathrm{N}$ and $85^{\circ} 10^{\prime}$ $-85^{\circ} 32^{\prime}$ E respectively. The valley ccovers a plain floor area about 640 sqkm and characterised by a typical monsoon climate with rainy summer (June-September) and dry winter (December-January) (Ghimire \& Bhuju 2005).Various studies concluded that the valley centered development caused to increase a lot of problems related to warming. And also, there have been various unusual weather events in Kathmandu valley since few decades.
This research has not covered the increasing trend of temperature and also not focused into impact analysis due to warming, the main objective was to classify the climate and determine, whether there was any changed in climatic types due to the present warming trend of Kathmandu valley by using weather elements like temperature and precipitation for the past 30 years (1976 to 2006).

Scientists have been using various methods to analyse the weather elements for classifying the climate around the world. There are three fundamental types (Empirical, Genetic and Applied) of classification used in climatology. In this paper empirical method (based on observable features) was used. The Wladimir Koppen's (German botanist and Climatologist) system is one of the most widely used empirical systems for classifying the climate (Kritchfield 2004).

Koppen's proposed his first classification in 1900, using the world vegetation map of a French Plant Physiologist de Candolle. This classification scheme uses certain critical values of temperature of the warmest and the coldest months and precipitation of 
the wettest and the driest months. Koppen aimed for an applied scheme that would relate climate to vegetation but provide an objective, numerical definition of climate types in terms of climatic elements. Later (1918) he revised it with greater attention to temperature, and their seasonal characteristics (Lal 1998).

In fact, the Koppen's classification is a descriptive system and the main purposed of classification is to organize a set of data. But in this paper, together classifying the climatic types there was also analyzed the frequency and determine the altered of climatic types of nine micrometeorological stations of Kathmandu valley.The climatic types and its changes were analyzed by comparing weather elements like temperature and precipitation with Koppen's empirical classification system (Method Table1, 2\& Classification Table 4). The frequency of regular occurrence of climatic types and its changes were also analyzed (Table 5 \&6)

\section{Materials and Methods \\ Data}

For basic climatic elements, rainfall and surface air temperature from 1976 to 2006 of 9sites (Kakani, Budhanilakantha, Godavari, Khumaltar, Airport, Panipokhari, Nagarkot, Khokana and Thankot) were collected from the Department of Hydrology and Meteorology, Government of Nepal. Out them, four stations ( Kakani, Godavari, Airport and Khumaltar )have both temperature and rainfall data. Other stations like Budhanilakantha (20 yrs), Panipokhari (27yrs), Nagarkot (22yrs) and Khokana (8yrs) have a limited recorded data for temperature and rainfall. Thankot has only precipitation data over a 30 years period.

\section{Methodology}

In this research the empirical method was used for Koppen's classification system. Particularly average seasonal temperatures (winter and summer) and total seasonal precipitation were used for analyse and comparison. The temperature of the winter season, December, January and February (DJF) was calculated as the arithmetic average of mean method. Similarly, the temperature of monsoon was calculated as the arithmetic average of mean temperature of June, July, August and September (JJAS) and compared with Koppen's classification system.

Koppen's system recognizes five principal categories of climates; each category is designated by a capital letter as shown in Table 1.

Table 1. Five principal categories of climates

\begin{tabular}{ll}
\hline Letter & Description \\
\hline A & Tropical humid climate. Winterless climate; it is hot all seasons; all months have a mean temperature above \\
& $18^{\circ} \mathrm{C}$ \\
B & Dry climates. In these climates evaporation exceeds precipitation; there is a constant water deficiency. \\
C & Humid mesothermal climates or warm temperate rainy climates. These climates have mild winters; the \\
average temperature of the coldest month is between $18^{\circ} \mathrm{C}$ and $-3^{\circ} \mathrm{C}$. In this group of climate the seasons, \\
winter and summer are found. \\
Humid micro thermal climates or cold forest climates. These climates have severe winters; the average \\
temperature of the coldest month is below $-3^{\circ} \mathrm{C}$ and that of the warmest month exceeds $10^{\circ} \mathrm{C}$ \\
Polar climates. These are summer less climates; the warmest monthly mean temperature is below $10^{\circ} \mathrm{C}$
\end{tabular}

The principal categories of climatic groups (A, C, D, and $\mathrm{E}$ ) are based on temperature characteristic, while the fifth, the B category, has precipitation as its fundamental criterion. Each of the five categories of climatic groups has been sub-divided on the basis of precipitation and temperature characteristics (Table 2). 
D. B. Kattel/Climatic Types, their Distribution.

Table 2. Sub division of five categories of climate on the basis of precipitation and temperature

\begin{tabular}{|c|c|c|c|}
\hline \multirow{3}{*}{$\begin{array}{l}\text { Letter Symbol } \\
\text { Ist } \\
\text { A }\end{array}$} & \multicolumn{3}{|r|}{ Precipitation and Temperature } \\
\hline & 2nd & $3 \mathrm{rd}$ & \\
\hline & \multicolumn{3}{|r|}{ Average temperature of the coldest month is $18^{\circ} \mathrm{C}$ or higher } \\
\hline \multicolumn{4}{|r|}{ Precipitation in driest month at least $6 \mathrm{~cm}$} \\
\hline & $\mathrm{m}$ & & $\begin{array}{l}\text { Short dry season; precipitation in driest month less than } 6 \mathrm{~cm} \text { but equal to or } \\
\text { greater than } 10-\mathrm{R} / 25(\mathrm{R} \text { is the annual rainfall in } \mathrm{cm})\end{array}$ \\
\hline & $\mathrm{w}$ & & Well-defined winter dry season; precipitation in driest month less than $10-\mathrm{R} / 25$ \\
\hline & s & & Well-defined summer dry season (rare) \\
\hline \multirow[t]{8}{*}{ B } & & & $\begin{array}{l}\text { Potential evaporation exceeds precipitation. The dry/humid boundary is defined } \\
\text { by the following formula. }\end{array}$ \\
\hline & & & $\begin{array}{l}\text { a) } \quad \mathrm{R}<2 \mathrm{~T}+28 \text { when } 70 \% \text { or more rainfall in warmer six months (April } \\
\text { through September in Northern Hemisphere). }\end{array}$ \\
\hline & & & $\begin{array}{l}\mathrm{R}<2 \mathrm{~T} \text { when } 70 \% \text { or more of rain falls in cooler six months (October } \\
\text { through March in Northern Hemisphere). }\end{array}$ \\
\hline & & & $\begin{array}{l}\mathrm{R}<2 \mathrm{~T}+14 \text { when neither half-year has } 70 \% \text { nor more rain. }(\mathrm{R} \text { is the } \\
\text { average annual precipitation in } \mathrm{cm} \text { and } \mathrm{T} \text { is average annual } \\
\text { temperature in }{ }^{\circ} \mathrm{C} \text {.) }\end{array}$ \\
\hline & $\mathrm{s}$ & & $\begin{array}{l}\text { Steppe/Desert the BS/BW boundary is } 1 / 2 \text { the dry/humid boundary ( } \mathrm{R} \text { less than } \\
\text { upper limit for B but more than } 1 / 2 \text { that amount). }\end{array}$ \\
\hline & $\mathrm{w}$ & & $\mathrm{R}$ less than $1 / 2$ upper limit of applicable requirement for $\mathrm{B}$ \\
\hline & & $\mathrm{h}$ & Average annual temperature is $18^{\circ} \mathrm{C}$ or greater \\
\hline & & $\mathrm{k}$ & Average annual temperature is less than $18^{\circ} \mathrm{C}$ \\
\hline \multirow[t]{7}{*}{$\mathbf{C}$} & & & $\begin{array}{l}\text { Average temperature of the warmest month greater than } 10^{\circ} \mathrm{C} \text { and of the coldest } \\
\text { month is under } 18^{\circ} \mathrm{C} \text { and above- }-3^{\circ} \mathrm{C} \text {. }\end{array}$ \\
\hline & w & & $\begin{array}{l}\text { At least ten times as much precipitation in summer month as in the driest } \\
\text { winter month }\end{array}$ \\
\hline & $\mathrm{s}$ & & $\begin{array}{l}\text { At least three times as much precipitation in winter month as in the driest summer } \\
\text { month; precipitation in driest summer month less than } 4 \mathrm{~cm} \text {. }\end{array}$ \\
\hline & $\mathrm{f}$ & & Criteria for w and s cannot be met. \\
\hline & & a & Average temperature of warmest month $22^{\circ} \mathrm{C}$ or above. \\
\hline & & $\mathrm{b}$ & $\begin{array}{l}\text { Average temperature of each of four warmest months } 10^{\circ} \mathrm{C} \text { or above; temperature } \\
\text { of warmest month below } 22^{\circ} \mathrm{C} \text {. }\end{array}$ \\
\hline & & $\mathrm{c}$ & $\begin{array}{l}\text { (Average temperature of from one to three months } 10^{\circ} \mathrm{C} \text { or above; temperature } \\
\text { of warmest month below } 22^{\circ} \mathrm{C} \text {. }\end{array}$ \\
\hline \multirow[t]{8}{*}{ D } & & & $\begin{array}{l}\text { Average temperature of coldest month is }\left(0^{\circ} \mathrm{C} \text { or below }\right)-3^{\circ} \mathrm{C} \text { or below; average } \\
\text { temperature of warmest month is greater than } 10^{\circ} \mathrm{C}\end{array}$ \\
\hline & $\mathrm{s}$ & & Same as under C \\
\hline & $\mathrm{w}$ & & Same as under $\mathrm{C}$ \\
\hline & f & & Same as under $\mathrm{C}$ \\
\hline & & a & Same as under $\mathrm{C}$ \\
\hline & & $\mathrm{b}$ & Same as under $\mathrm{C}$ \\
\hline & & $\mathrm{c}$ & Same as under C \\
\hline & & $\mathrm{d}$ & Average temperature of the coldest month is $-38^{\circ} \mathrm{C}$ or below \\
\hline \multirow[t]{3}{*}{$\mathbf{E}$} & & & Average temperature of the warmest month is below $10^{\circ} \mathrm{C}$ \\
\hline & $\mathrm{T}$ & & Average temperature of the warmest month is between $0^{\circ} \mathrm{C}$ and $10^{\circ} \mathrm{C}$ \\
\hline & $\mathrm{F}$ & & Average temperature of the warmest month is $0^{\circ} \mathrm{C}$ or below \\
\hline $\mathbf{H}$ & & & Temperature requirement same as $\mathrm{E}$, but due to altitude (generally above $1500 \mathrm{~m}$ ) \\
\hline
\end{tabular}

Table 1 and 2 are based on W.Koppen, Goundriss der klimakunde (Berlin: Walter de Gruyter Company, 1931); W. Koppen, "Das geographische system der klimate," Vol I,
Part C of W. Koppen and R.Geiger, Handbuch des klimatologie (Berlin: Gebruder Borntraegar, 1936): and modifications by R.Geiger, R.J. Russel Glenn T.Trewartha, and others. 


\section{Result and Discussion}

\section{Temperature and precipitation variation}

Slightly variation in temperature was found at the eight meteorological stations of Kathmandu valley. The average seasonal winter temperature was found maximum $\left(11.55^{\circ} \mathrm{C}\right)$ at the airport during 1976-2006. Similarly, the average seasonal summer temperature was also found maximum $\left(23.78^{\circ} \mathrm{C}\right)$ at the airport. Comparing with the baseline year 1976, the winter temperature at Kakani was $9.15^{\circ} \mathrm{C}$, than the temperature which reached maximum in $2006\left(12.01^{\circ} \mathrm{C}\right)$. Similarly, compared to the base line year 1976, the summer temperature at the airport was $23.63^{\circ} \mathrm{C}$, then it was reached $24.75^{\circ} \mathrm{C}$ in 2005 . However, the increasing trend of temperature of Kathmandu valley was $0.8^{\circ} \mathrm{C}$ per decade and $0.08^{\circ} \mathrm{C}$ per year (Fig. 1)

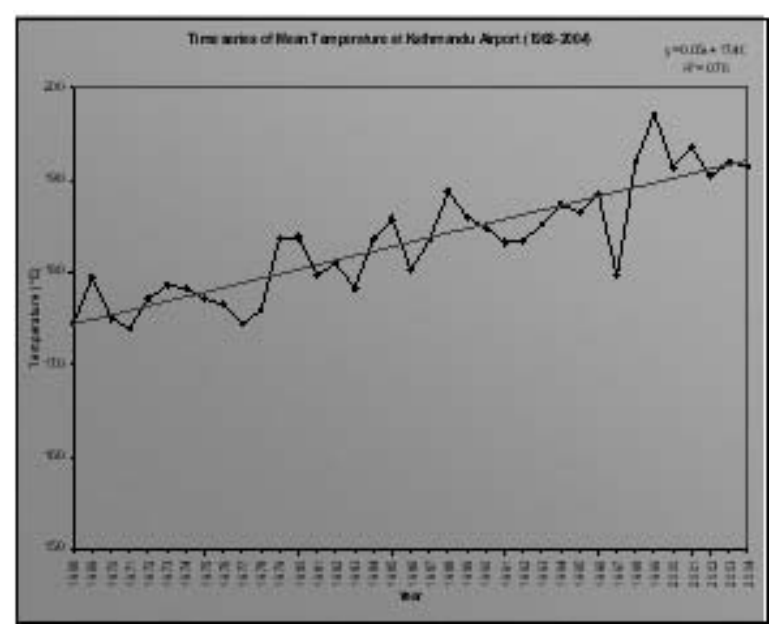

Fig 1. Time series of mean temperature at Kathmandu airport

Table 3. Seasonal 30 years (1976-2006) average temperatures and total precipitation at different stations in Kathmandu valley

\begin{tabular}{llllllllllllllll} 
Station & \multicolumn{2}{c}{ Kakani } & \multicolumn{3}{c}{ Godavari } & \multicolumn{4}{c}{ Khumaltar } & \multicolumn{2}{c}{ Airport } & \multicolumn{2}{c}{ Panipokhari } & \multicolumn{2}{c}{ Nagarkot } \\
\hline & $\mathrm{W}$ & $\mathrm{S}$ & $\mathrm{W}$ & $\mathrm{S}$ & $\mathrm{W}$ & $\mathrm{S}$ & $\mathrm{W}$ & $\mathrm{S}$ & $\mathrm{W}$ & $\mathrm{S}$ & $\mathrm{W}$ & $\mathrm{S}$ & $\mathrm{W}$ & $\mathrm{S}$ & \\
\hline Temp. $\left({ }^{\circ} \mathrm{C}\right)$ & 9.31 & 19.00 & 10.06 & 21.42 & 10.65 & 23.38 & 11.55 & 23.78 & 11.32 & 23.63 & 8.89 & 18.71 & DNA & DNA \\
\hline Precipitation.(cm) & 177.53 & 6890.12 & 186.99 & 4232.77 & 151.69 & 2715.58 & 153.74 & 3509.32 & 104.61 & 3029.67 & 142.05 & 4495.55 & 205.58 & 4555.39
\end{tabular}

W: Winter

S: Summer

DNA; Data not available

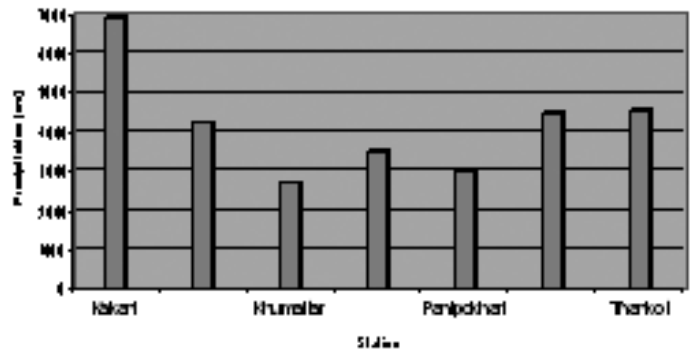

Fig 2. Total precipitation $(\mathrm{cm})$ at different stations in summer (1976-2006)

Analyzing the rainfall parameter, seasonal precipitation distribution was found dissimilar for different stations (Fig.2 and 3). The thirty years total seasonal precipitation (Table 3 ) in summer was found maximum at Kakani (6890.12cm, Fig. 2) and minimum at Khumaltar (2715.58cm, Fig.2). Similarly, the seasonal precipitation in winter months was found maximum at Thankot (205.58cm, Fig. 3) and minimum at Khumaltar (151.69cm Fig.3). The maximum precipitation was

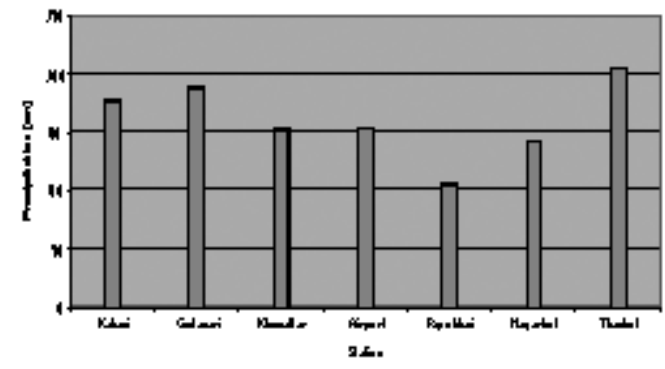

Fig3. Total precipitation $(\mathrm{cm})$ at different stations in winter (1976-2006)

recorded in summer season at Kakani.However in winter season the maximum precipitation was recorded at Thankot (Table 3).

\section{Distributions of climatic types}

Analyzing both the meteorological parameters temperature and precipitation, all micrometeorological stations of Kathmandu valley were found as " $C$ " Major type of climate. "C" type of climate is normally humid 
D. B. Kattel/Climatic Types, their Distribution.

mesothermal that is also known as warm temperate rainy climate. This type of climate is a mild winter, having the average temperature of the coldest month below $18^{\circ} \mathrm{C}$ and above $-3^{\circ} \mathrm{C}$ and the average temperature of the warmest month is above $10^{\circ} \mathrm{C}$ (Table 1 ).

Comparing with rainfall parameter, all stations of Kathmandu valley were found "w" sub type of climate (Table 4). "W" sub type of climate is particularly the dry winter's type of climate. In this sub type of climate, at least 10 times as much precipitation in wettest month (JJAS) or precipitation in driest month (DJF) is less than $1 / 10$ amount in wettest summer month. Therefore, from this study all winter seasons of different stations of Kathmandu valley were found dry.
The positive frequency of "w" sub type of climate (Table 5) in numbers of years at Kakani was 29 (out of 31 years), Budhanilakantha 20 (out of 20 years), Godavari was 29 (out of 31 years), Khumaltar 28 (out of 31 years), Airport 31 (out of 31 years), Panipokhari 27 (out of 27 years), Nagarkot 31 (out of 31 years), Khokana 12 (out of 15 years) and Thankot 29 (out of 31 years).

However, the " $\mathrm{f}$ " sub type of climate was also found in different stations. The frequency of "f" sub type of climate at Kakani and Budhanilakantha was 0 out of 31 and 20 years respectively. Similarly the changed frequency at Godavari, Khumaltar, Airport, Nagarkot and Thankot were 1,4,0,0 and 2 respectively out of 31 years and Panipokhari and Khokana were 0 and 3 out of 27 and 15 year years respectively (Table 5).

Table 4. Climatic types of each stations of Kathmandu valley

\begin{tabular}{|c|c|c|c|c|c|c|c|c|c|}
\hline Year & Kakani & Budhanilakantha & Godavari & Khumaltar & Kathmandu Airport & Panipokhari Kathmandu & Nagarkot & Khokana & Thankot \\
\hline 1976 & Cwb & & Cwb & $\mathrm{Cw}^{*}$ & Cwa & Cwa & $\mathrm{CW}^{*}$ & & $\mathrm{CW}^{*}$ \\
\hline 1977 & Cwb & & Cwb & Cwa & Cwa & Cwa & $\mathrm{Cw}^{*}$ & & $\mathrm{Cw}^{*}$ \\
\hline 1978 & Cwb & & Cwb & Cwa & Cwa & Cwa & $\mathrm{CW}^{*}$ & & $\mathrm{Cw}^{*}$ \\
\hline 1979 & & & $\mathbf{C f b}$ & Cfa & Cwa & $\mathrm{Cw}^{*}$ & $\mathrm{CW}^{*}$ & & $\mathrm{Cw}^{*}$ \\
\hline 1980 & Cwb & & Cwb & Cwa & Cwa & Cwa & $\mathrm{CW}^{*}$ & & $\mathrm{Cw}^{*}$ \\
\hline 1981 & Cwb & & Cwb & Cwa & Cwa & Cwa & $\mathrm{CW}^{*}$ & & $\mathrm{Cw}^{*}$ \\
\hline 1982 & Cwb & & Cwb & Cwa & Cwa & Cwb & $\mathrm{CW}^{*}$ & & $\mathrm{CW}^{*}$ \\
\hline 1983 & Cwb & & Cwb & Cwa & Cwa & Cwa & $\mathrm{CW}^{*}$ & & $\mathrm{Cw}^{*}$ \\
\hline 1984 & Cwb & & Cwb & Cwa & Cwa & Cwa & $\mathrm{CW}^{*}$ & & $\mathrm{CW}^{*}$ \\
\hline 1985 & Cwb & & Cwb & Cwa & Cwa & Cwa & Cwb & & $\mathrm{Cw}^{*}$ \\
\hline 1986 & Cwb & & Cwb & Cwa & Cwa & Cwa & Cwb & & $\mathrm{Cw}^{*}$ \\
\hline 1987 & Cwb & Cwa & Cwb & Cwa & Cwa & Cwa & Cwb & & $\mathrm{Cw}^{*}$ \\
\hline 1988 & Cwb & Cwa & Cwb & Cfa & Cwa & Cwa & Cwb & & $\mathrm{CW}^{*}$ \\
\hline 1989 & Cwb & Cwa & Cwb & Cwa & Cwa & & Cwb & & $\mathrm{CW}^{*}$ \\
\hline 1990 & Cwb & Cwa & Cwb & Cwa & Cwa & & Cwb & & $\mathrm{CW}^{*}$ \\
\hline 1991 & Cwb & Cwa & Cwb & Cwa & Cwa & Cwa & Cwb & & $\mathrm{Cw}^{*}$ \\
\hline 1992 & $\mathrm{Cw}^{*}$ & Cwa & Cwb & Cwa & Cwa & Cwa & Cwb & $\mathrm{Cw}^{*}$ & $\mathrm{Cw}^{*}$ \\
\hline 1993 & & Cwa & Cwa & Cwa & Cwa & & Cwb & $\mathrm{CW}^{*}$ & $\mathrm{CW}^{*}$ \\
\hline 1994 & Cwb & Cwa & Cwb & Cwa & Cwa & & Cwb & $\mathrm{Cw}^{*}$ & $\mathrm{CW}^{*}$ \\
\hline 1995 & Cwb & Cwa & Cwb & Cwa & Cwa & Cwa & Cwb & $\mathrm{CW}^{*}$ & $\mathrm{CW}^{*}$ \\
\hline 1996 & Cwb & Cwa & Cwb & Cwa & Cwa & Cwa & Cwb & $\mathrm{Cw}^{*}$ & $\mathrm{Cw}^{*}$ \\
\hline 1997 & Cwb & Cwa & Cwb & Cfa & Cwa & Cwa & Cwb & Cf** & $\mathrm{Cw}^{*}$ \\
\hline 1998 & Cwb & Cwa & $\mathrm{Cb}^{* *}$ & Cwa & Cwa & Cwa & Cwb & $\mathrm{CW}^{*}$ & $\mathrm{Cw}^{*}$ \\
\hline 1999 & Cwb & Cwa & Cwb & Cwa & Cwa & Cwa & Cwb & Cwa & $\mathrm{CW}^{*}$ \\
\hline 2000 & Cwb & Cwa & Cwb & Cwa & Cwa & Cwa & Cwb & Cwa & $\mathrm{CW}^{*}$ \\
\hline 2001 & Cwb & Cwa & Cwb & Cwa & Cwa & Cwa & Cwb & Cwa & $\mathrm{CW}^{*}$ \\
\hline 2002 & Cwb & Cwa & Cwb & Cwa & Cwa & Cwa & Cwb & Cwa & $\mathrm{Cw}^{*}$ \\
\hline 2003 & Cwb & Cwa & Cwb & Cwa & Cwa & Cwa & Cwb & Cfa & Cf $* *$ \\
\hline 2004 & Cwb & Cwa & Cwb & Cwa & Cwa & Cwa & Cwb & Cwa & $\mathrm{Cw}^{*}$ \\
\hline 2005 & Cwb & Cwa & Cwa & Cfa & Cwa & Cwa & Cwb & Cfa & Cs $* *$ \\
\hline 2006 & Cwb & Cwa & Cwb & Cwa & Cwa & Cwa & Cwb & Cwa & $\mathrm{Cw}^{*}$ \\
\hline
\end{tabular}

* Missing Temperature Data

** Missing Precipitation Data

The "f" sub type climate is as the "moist type of climate, particularly having wet all seasons. At least $3 \mathrm{~cm}$ precipitation is found in this sub type of climate in the driest month, the difference between wettest month and driest month is less than for "'w" and "s" (Table 2). 
Analyzing the temperature parameter ' $b$ " subtype of climate (Table 4) was found in Kakani, Godavary and Nagarkot and "a" sub-type climate found at Budhanilakantha, Khumaltar, Airport, Panipokhari and Khokani (Table 4 and 5). However, the "a" sub-type of climate was also found at Godavari and "b" sub-type found in Panipokhari but the changed frequency was very less (Table 4 and 5). The changed frequency of "a" sub- type climate at Godavari was 2 (out of 31 years) and changed frequency of " $b$ " sub- type of climate at Panipokhari was 1 (out of 26 years) (Table 4 and 5).

The "a" sub-type of climate is as the hot summer type of climate. In this sub-type of climate, the average temperature of the warmest month is greater than $22^{\circ} \mathrm{C}$ or above and at least four months over $10^{\circ} \mathrm{C}$ (Table 2).

The "'b" sub type of climate is particularly cool summer type that has average temperature of each four month below $22^{\circ} \mathrm{C}$ (Table 2 ).

Table 5. Frequency of year climate for the years 1976-2006

\begin{tabular}{|c|c|c|c|c|c|c|c|c|c|c|c|}
\hline No. & Observation station & Elevation (m) & Cwa & Cwb & $\mathrm{Cw}$ & $\mathrm{Cfb}$ & Cfa & $\mathrm{Cf}$ & $\mathrm{Cb}$ & $\begin{array}{l}\text { No Year Data } \\
\text { Temp }\left({ }^{\circ} \mathrm{C}\right)\end{array}$ & $\begin{array}{l}\text { No Year Data } \\
\text { Pcpn }(\mathrm{cm})\end{array}$ \\
\hline 1 & Nagarkot & 2163 & 0 & 22 & 9 & 0 & 0 & 0 & 0 & 9 & 0 \\
\hline 2 & Kakani & 2064 & 0 & 28 & 1 & 0 & 0 & 0 & 0 & 2 & 1 \\
\hline 3 & Buddhanilkantha & 1350 & 20 & 0 & 0 & 0 & 0 & 0 & 0 & 11 & 11 \\
\hline 4 & Godavari & 1400 & 2 & 27 & 0 & 1 & 0 & 0 & 1 & 1 & 1 \\
\hline 5 & Khumaltar & 1350 & 26 & 0 & 1 & 0 & 4 & 0 & 0 & 1 & 0 \\
\hline 6 & Kathmandu Airport & 1336 & 31 & 0 & 0 & 0 & 1 & 0 & 0 & 0 & 0 \\
\hline 7 & Panipokhari & 1335 & 26 & 1 & 1 & 0 & 0 & 0 & 0 & 4 & 4 \\
\hline 8 & Khokana & 1212 & 6 & 0 & 6 & 0 & 2 & 1 & 0 & 23 & 16 \\
\hline 9 & Thankot & 1630 & 0 & 0 & 29 & 0 & 0 & 2 & 0 & 31 & 0 \\
\hline
\end{tabular}

The "Cwa" and "Cwb" types of climates were not common for all stations individually in Kathmandu valley. To determine these types of climate, both precipitation and temperature parameters were taken for comparison with Kopen's system (Table 4). From the analytical studies of the temperature and precipitation data, the "Cfa "and "Cfb" type of climates were also found in some stations. Particularly the "Cwa" type of climate was found at Budhanilkantha, Khumaltar, Airport, Panipokhari and Khokana (Table 4 and 5). And, the "Cwb" type of climate was found at Kakani, Godavari and Nagarkot (Table 4 and 5).

However, the changes of "Cwa" type of climate was also found at Godavari but the frequency was 2 out of 30 years and the changes of "Cwb" type of climate also found at Panipokhari but the frequency was 1 out of 26 years (Table 4 and 5).

The "Cwa" type of climate particularly known as subtropical monsoon type that has mild winter and hot summer. Similarly, "Cwb" type of climate is tropical upland type in this type of climate there is found winter dry and short summer (Table 1 and 2).

Comparison with "Cwa" and "Cwb" types of climate, the "Cfa" type was found only at Khumaltar and Khokana and "Cfb" type was found only at Godavari. The frequency of "Cfa" type of climate was 4 (out of 30 years) at Khumaltar and Khokana was 2 (out of 8 years). Similarly, the frequency of "Cfb" type of climate at Godavari was 1 (out of 31 years).

The "Cfa" type of climate is a humid subtropical particularly moist all seasons but long hot summer. And, "Cfb" type of climate is mild winter like "Cfa" and moist all seasons but short cool summer (Table 1 and 2).

\section{Changes of climatic types}

Analyzed of two meteorological parameters, precipitation and temperature and compared with Koepen's systems were not found any alarming result on changes of climatic type's even increasing temperature of Kathamndu valley. The changes 
D. B. Kattel/Climatic Types, their Distribution.

frequency of climatic types was minimum as compared to over all climatic types of Kathmandu valley. Within the period of 1976 to 2006, the changes of climatic types were found only at Godavari, Khumaltar, Panipokhari and Thankot, however the frequency was very less as compared 30 years period (Table 5\&6).

Table 6. The changes frequency of climate types

\begin{tabular}{|c|c|c|c|c|c|c|c|c|c|c|c|c|c|}
\hline \multicolumn{2}{|c|}{ Station/Year/Parameter } & & \multicolumn{2}{|c|}{ Cwa } & \multicolumn{4}{|c|}{$\mathrm{Cfa}$} & \multirow[t]{2}{*}{ Cwb } & \multirow{2}{*}{$\begin{array}{c}\mathrm{Cfb} \\
1979\end{array}$} & \multicolumn{2}{|c|}{$\mathrm{Cf}$} & $\mathrm{Cb}$ \\
\hline \multirow[t]{5}{*}{ Godavari } & Year & & 1993 & 2005 & & & & & & & & & 1998 \\
\hline & $\mathrm{Temp}^{\circ} \mathrm{C}$ & $\mathrm{w}$ & 11.21 & 10.83 & & & & & & 9.52 & & & 10.22 \\
\hline & & $\mathrm{s}$ & 22.55Max & 22.32 & & & & & & 21.77 & & & DNA \\
\hline & Pcpn $(\mathrm{cm})$ & w & 3.5 & 8.71 & & & & & & $\begin{array}{l}13.73 \\
\text { Max }\end{array}$ & & & 3.22 \\
\hline & & $\mathrm{s}$ & 159.4 & 101.77Min & & & & & & 129.37 & & & DNA \\
\hline \multirow[t]{5}{*}{ Khumaltar } & Year & & & & 1979 & 1988 & 1996 & 2005 & & & & & \\
\hline & $\mathrm{Temp}^{0} \mathrm{C}$ & $\mathrm{w}$ & & & 9.46Min & 11.56 & 10.93 & 11.31 & & & & & \\
\hline & & $\mathrm{s}$ & & & 22.73 & 23.12 & 23.18 & 24.07 & & & & & \\
\hline & $\operatorname{Pcpn}(\mathrm{cm})$ & $\mathrm{w}$ & & & $10.84 \mathrm{Max} 3$ & 14.2Max 1 & 11.59Max & 6.97Max4 & & & & & \\
\hline & & $\mathrm{s}$ & & & 76.49 & 106.6 & 77.35 & 59.56 & & & & & \\
\hline \multirow[t]{5}{*}{ Panipokhari } & Year & & & & & & & & 1982 & & & & \\
\hline & $\mathrm{Temp}^{0} \mathrm{C}$ & $\mathrm{w}$ & & & & & & & 10.25 & & & & \\
\hline & & $\mathrm{s}$ & & & & & & & 20.55 & & & & \\
\hline & $\operatorname{Pcpn}(\mathrm{cm})$ & $\mathrm{w}$ & & & & & & & 4.8 & & & & \\
\hline & & $\mathrm{s}$ & & & & & & & 93.51 & & & & \\
\hline \multirow[t]{5}{*}{ Khokana } & Year & & & & 2003 & 2005 & & & & & 1997 & & \\
\hline & $\mathrm{Temp}^{\circ} \mathrm{C}$ & $\mathrm{w}$ & & & 10.31 & 10.56 & & & & & & & \\
\hline & & $\mathrm{s}$ & & & 23.63 & 23.80 & & & & & & & \\
\hline & $\operatorname{Pcpn}(\mathrm{cm})$ & $\mathrm{w}$ & & & 13.62 & 9.44 & & & & & 13.72 & & \\
\hline & & $\mathrm{s}$ & & & 124.01 & 76.88 & & & & & 92.41 & & \\
\hline \multirow[t]{6}{*}{ Thankot } & Year & & & & & & & & & & 2003 & 2005 & \\
\hline & $\mathrm{Temp}^{\circ} \mathrm{C}$ & $\mathrm{w}$ & & & & & & & & & DNA & DNA & \\
\hline & & $\mathrm{s}$ & & & & & & & & & DNA & DNA & \\
\hline & $\operatorname{Pcpn}(\mathrm{cm})$ & w & & & & & & & & & $\begin{array}{r}13.54 \\
\operatorname{Max} 1\end{array}$ & & \\
\hline & & $\mathrm{s}$ & & & & & & & & & 121.66 & 85.68 & \\
\hline & & & & & & & & & & & $\operatorname{Max} 2$ & & \\
\hline
\end{tabular}

The average climatic type of Godavari was "Cwb". The changes into "Cwa" type of climate occurred in 1993 and 2005 from "Cwb". In 1993 the summer temperature of Godavari reached maximum $\left(22.55^{\circ} \mathrm{C}\right)$ and also highest $\left(22.32^{\circ} \mathrm{C}\right)$ in 2005 during the period 1976-2006. In 2005, the precipitation recorded minimum as compared to other stations at Godavari. Therefore, the changes frequency of "Cwa" type of climate was 2 during this period. Similarly, the "Cfb" type of climate was also found at Godavari in 1979 but the frequency was only 1 (Table 5\&6).

The average climatic type of Khumaltar was "Cwa". The changes in to "Cfa" type of climate occurred in 1979, 1988, 1996 and 2005. The winter temperature reached minimum $\left(9.46^{\circ} \mathrm{C}\right)$ in 1979 within the period of 30 years. And, the maximum precipitation was recorded $10.84 \mathrm{~cm}$ in $1979,14.2 \mathrm{~cm}$ in 1988 , and $11.59 \mathrm{~cm}$ in 1996 and $6.97 \mathrm{~cm}$ in 2005 .The frequency of "Cfa" type of climate at Khumaltar was found 4 out of
30 years. It is the calculated highest frequency of changes of climatic types as compared to other stations of this research (Table 5\&6).

Similarly the average type of climate of Panipokhari was "Cwa". The changes occurred in 1982 into "Cwb" type of climate, but the changes in frequency of climatic type was only one.

\section{Acknowledgement}

The author would like to thank Dr. Dinesh Raj Bhuju for his kind suggestions and encouragement, and to Mrs. Ramila Raut, Mr. Sishir Raj Kolachhapati, Mr. Bhojraj Adhikari and Mrs. Parbati Pudasaini for their constant inspiration to complete this research. The author is also thankful to the Department of Hydrology and Meteorology for providing the data. Mr. Binod Dawadi is highely acknowledgeed for his sincere help in this research. 


\section{References}

Barry, R.G. and R. J. Chorley. 2003. Atmosphere, weather and climate. ( $8^{\text {th }}$ edition). Routledge Taylor and Francis Group Publishers, London. pp. 391-392.

Bhatta, S.D. 2004. Are electric vehicles viable in Kathmandu? A cost-benefit perspective. Winrock International, Kathmandu, Nepal.

Devkota, L.P. 2004. Climate variability over Nepal: Observations, forcasting, model evaluation and impacts on agriculture and water resources.Ph.D. dissertation. Tribhuvan University, Kathmandu, Nepal.

Ghimire, R., D.R. Bhuju and H.R. Maharjan. 2005. Vegetation ecology and soil of Bhandarkhal forest at Pashupati area, Kathmandu. Nepal Journal of Science and Technology 6:27-35.

IPCC. 2007. Impacts, adaptation and vulnerability. Working Group II Contribution to the Inter Governmental Panel on Climate Change Fourth Assessment Report.

Kellogg, W.W. and R. Schware. 1982. Climate change \& Society. Westview Press/Boulder, Colorado.

Kritchfield, H.J. 2004. General climatology. Publish by A.K. Ghosh, Prentice Hall India. pp. 145-161.
Lal, D.S. 1998. Climatology. Chaitanya Publishing House Allahabad, India, pp. 316-376.

MoPE, UNEP/ROAP. 2000. Mitigating the effect of climate change. Report of National Workshop UNFCC and Institutional Design of the Cooperative Implementation Mechanisms of Kyoto Protocal. Ministry of Population and Environment, Nepal.

Shrestha, A. B. 1999. Maximum temperature trend in the Himalaya and its vicinity: An analysis base on temperature records from Nepal for the period 19711994. Journal of Climate. Vol. 12 pp. 2775-2786.

Stringer, E.T.1982. Foundations of climatology. Surjeet Publications, India. pp 21-25.

Wagle, P. \& D. B. Kattel. 2007. Warming of the Kathmandu valley: Promotion towards global warming. Nepal Academy of Science and Technology.

Yoshino, M.M. 1975.Local climatology differences between highlands and low lands in Thailand. Website:http:// www.unu.edu/unupress/unupbooks/80077e/ 80077E0a.htm 